Jurnal Agribis

Vol. 7, No.1, Tahun 2021

\title{
INOVASI PENGOLAHAN PEPAYA MENJADI SWIR PEPAYA GORENG SEBAGAI UPAYA PENINGKATAN NILAI EKONOMI
}

\author{
Mufida Diah Lestari', Siti Nur Nafi'ah ${ }^{2}$, Aisy Intan Nabilah ${ }^{3}$, Anas Nur Azizah ${ }^{4}$ \\ 1. Program Studi Agribisnis, Fakultas Pertanian, Universitas Tulungagung \\ 2,3,4 Program Studi Manajeman, Fakultas Ekonomi, Universitas Tulungagung
}

5

E-mail: Mufida.dl85@gmail.com

\begin{abstract}
ABSTRAK
Proposal ini membahas tentang inovasi baru dalam menambah nilai serta manfaat dari buah pepaya. Buah pepaya sangat familiar oleh masyarakat terutama di Indonesia, merupakan buah yang memiliki ciri fisik yaitu berwarna orange ketika sudah masak dan berwarna hijau ketika masih mentah. Pepaya merupakan buah yang mengandung banyak vitamin A dan C. Pada umumnya pepaya hanya dimanfaatkan untuk dijadikan rujak,sayur dan dimakan secara langsung. Kegunaan pepaya sebagai sumber vitamin A yang mana vitamin A bermanfaat untuk membantu proses reproduksi dan kesehatan pada mata. Selain itu pepaya juga mengandung vitamin $C$ yang bermanfaat untuk memperbaiki jaringan sel kulit dan mengurangi resiko serangan jantung. Tentunya hal ini sangat bermanfaat bagi tubuh manusia termasuk mahasiswa. Oleh karena itu, untuk menambah daya tarik dari buah pepaya, kini diciptakan alternative baru agar masyarakat tertarik untuk mengonsumsinya, yakni dengan membuat inovasi buah pepaya menjadi swir pepaya goreng sebagai peningkatan mutu nilai ekonomi buah pepaya.
\end{abstract}

Kata Kunci: pepaya, inovasi, nilai ekonomi

\section{ABSTRACT}

This proposal discusses new innovations in adding value and benefits to the papaya fruit. Papaya fruit is very familiar to people, especially in Indonesia, is a fruit that has physical characteristics, namely orange when it is ripe and green when it is still raw. Papaya is a fruit that contains lots of vitamins $A$ and $C$. In general, papaya is only used for salad, vegetables and eaten directly. The use of papaya as a source of vitamin $A$ which vitamin $A$ is useful for helping the reproductive process and eye health. In addition, papaya also contains vitamin $C$ which is useful for repairing skin cell tissue and reducing the risk of heart attack. Of course this is very beneficial for the human body, including students. Therefore, to increase the attractiveness of papaya fruit, a new alternative is being created so that people are interested in consuming it, namely by making papaya fruit innovation into self-fried papaya as an increase in the quality of the economic value of papaya.

Keywords: papaya, innovation, economic value 


\section{PENDAHULUAN}

\section{Latar Belakang}

Di Indonesia buah pepaya sangat mudah didapat, serta memiliki harga yang murah murah. Tetapi nuah papaya memilliki kandungan vitamin yang cukup banyak dianatranya adalah Vitamin A, C dan juga $E$ yang baik bagi tubuh. Zat-zat yang terkandung didalamnya berfungsi baik bagi kesehatan kulit, diantaranya menjaga kelembapan kulit, membantu proses regenerasi sel kulit, serta mengatasi kulit kusam. Jumlah kandungan kalori yang dimiliki buah pepaya sangat rendah, dan buah ini tidak mengandung kolesterol.

Masyarakat di Indonesia banyak yang menanam pohon pepaya didataran rendah sampai ketinggian $700 \mathrm{~m}$ diatas permukaan laut. Salah satu daerah yang sangat cocok ditanami buah pepaya adalah daerah Tulungungung. Di Tulungagung banyak ditemukan buah pepaya dengan cara konsumsi yang monoton seperti rujak buah, jus,dan dimakan secara langsung. Oleh karena itu masyarakat merasa kurang tertarik cara konsumsi tersebut. Saat ini minat untuk mengkonsumsi papaya sangat berkurang banyak. Untuk itu peneliti tangh berupaya mengajak para ibu-ibu rumah tangga di wilayah Kabupaten Tulungagung untuk membuat papaya supaya lebih menarik dan memiliki nilai jual yang lebih tinggi. Usaha yang dapat dilakukan adalah memberikan pelatihan kepada ibu-ibu untuk mengolah papaya menjad swir pepaya goreng dengan varian rasa modern.

Peneliti dalam hal ini mencoba invovasi baru dengan membuah papaya dengan olahan yang lebih menarik sehingga harapannya adalah memeberikan minat bagi konsumen untuk menikmati papaya dengan variasi yang berbeda.

\section{Tujuan}

Tujuan dari penelitian ini adalah mengajak para ibu-ibu pada kelompokkelompok tertentu mengisi waktu luang sebagai upaya meningkatkan perekonomian keluarga di wilayah Kabupaten Tulungagung melalui produksi olahan papaya menjadi swir papaya goreng.

\section{METODE PENELITIAN}

Pada penelitian ini, peniliti memilih Kabupaten Tulunggung karena didaerah Tulungagung banyak ditemukan masyarakat yang menanam pohon pepaya, untuk masyarakat yang menjadi sasaran adalah kalompok-kelompok ibu rumah tangga yang supaya bisa membantu masyarakat untuk meningkatkan perekonmian keluarga. Dari metode ini dilakukan beberapa langkah diantaranya adalah:

\section{A. TAHAP PERSIAPAN}

Peralatan yang harus dipersiapkan untuk mengolah swir pepaya goreng adalah alat serut untuk memarut pepaya, blender, wajan, pisau, spatula, serok, mesin spiner untuk mengeringkan minyak pada swir pepaya goreng. 
Bahan baku utama untuk pembuatan swir pepaya goreng adalah buah pepaya muda, garam, ketumbar bubuk, merica bubuk, kunyit, jinten. Kesemua bahan ini mudah didapatkan dipasaran serta harganya pun cukup terjangkau. Buah pepaya juga bukan tanaman musiman sehingga bisa didapatkan kapan saja.

\section{B. TAHAP PENGOLAHAN}

Pengolahan swir pepayagoreng

a. Kupas pepaya terlebihdahulu

b. Cuci pepaya yang telah dikupas hinggabersih

c. Parut pepaya muda dan rendam dengan airgaram

d. Cuci serutan pepaya muda dan masukkan kedalambaskom

e. Setelah itu peras secara perlahan-lahan agar kandungan air yang terdapat di serutan pepaya hilang

f. Blender bumbu - bumbu yang sudahdisiapkan

g. Campurkan tepung kanji, tepung beras, dan bubukkaldu

h. Campur serutan pepaya dengan bumbu yang sudah diblender aduk sampai rata

i. Setelah itu masukkan serutan pepaya yang sudah dibumbui ke dalam tepung yang sudah tercampur olehbumbu

j. Nyalakan kompor dan siapkan alatpenggorengan

k. Tunggu minyak panas lalu masukkan serutan pepaya yang sudah dibumbui, masak hingga warnakecoklatan

I. Masukkan kedalam mesin spiner agar minyak yang adaberkurang

$\mathrm{m}$. Setelah itu beri rasa seperti balado,ayam panggangdll.

n. Swir pepaya goreng siapdihidangkan.

\section{Evaluasi}

Tahap evaluasi dilaksanakan untuk mengetahui sejauhmana pengetahuan dan keahlian ibu-ibu rumah tangga dalam mengolah papaya menjadi swir papaya.

\section{TAHAP PROMOSI}

Produk ini juga akan dipublikasikan dengan memasang iklan menggunakan media sosial dan media cetak seperti brosur, penyebaran brosur kemasyarakat luas, dan informasi dari mulut ke mulut.

\section{HASIL DAN PEMBAHASAN}

\section{A. SUMBER BAHANBAKU}

Bahan baku utama adalah buah pepaya. Buah pepaya ini banyak ditemukan di depan perkarangan rumah, di Tulungagung sendiri banyak sekali orang yang menanam pohon pepaya. Papaya merupakan ssalah satu buah yang mudah dijumpai dipasar dan tidak jarang banyak ditanam di lahan pekarangan masyrakat. Papaya memiliki fungsi serta kandungan yang cukup baik bagi tubuh manusia karena mengandung vitamin-vitamin yang dibperlukan oleh tubuh manusia. 
Selama ini masyarakat mengkonsumsi buah papaya dalam bentuk buah saja dan tidak diolah. Untuk itu banyak masyarakat yang mulai enggan untuk mengkonsumsi buah papaya, sehingga buah mengalami penurunan nilai ekonomi karena tidak begitu laku dijual dipasaran.

Buah papaya juga memiliki fungsi baik bagi kesehatan karena dapat menurunkan resiko sakit jantung, kanker, diabetes. Membantu proses pencernaan, menurunkan tekanan darah. Untuk itu papaya sangat baik dikonsumsi oleh tubuh manusia. Buah papaya tidak hanya dapat digunakan untuk buah-buahan namun juga dapat digunakan untuk membuat sayur yang dimasak, daun papaya juga dapat dimanfaatkan untuk memasak dan memiliki khasiat yang cukup baik bagi tubuh. Oleh karena itu buah papaya memiliki banyak manfaat bagi masyarakat.

\section{B. DESKRIPSI PRODUK}

Wris papaya goreng merupakan sebuah hasil olahan dari buah papaya yang diiris tipis, dikeringkan kemudian digoreng lalu diberikan varian rasa yang bermacam-macam menyesuaikan dengan selera anak muda saat ini.

Produk olahan buah pepaya ini akan dikemas dengan kemasan semenarik mungkin untuk meningkatkan minat pembeli. Dengan adanya produk swir papaya goreng ini juga dapat meningkatkan nilai jual pepaya dan membantu pengembangan olahan makanan dari buahpepaya.

\section{PELUANG USAHA}

Ada beberapa hal yang bisa membuat swir pepaya goreng ini mampu diterima oleh pasardiantaranya

- Inovasi produk swir pepaya goreng ini sangat mudah dikembangkan salah satunya dengan menambahkan varian rasa sehingga calon konsumen tidak bosan untukmengonsumsinya.

- Bahan dasar pembuatan swir pepaya goreng ini sangat mudah sekali didapatkan dipasaran, dan harganya relatif terjangkau, sehingga dapat membuka peluang pada siapa saja untuk membuka usaha swir pepaya goreng.

\section{PElUang Pendapatanusaha}

Usaha swir pepaya goreng memang sudah banyak ditekuni oleh masyarakat, namun mereka belum mengetahui tentang manfaat lain dari swir papaya goreng selain untuk camilan. Banyak manfaat yang terkandung dalam buah pepaya adalah dapat dikonsumsi oleh masyarakat karena kaya akan vitamin dan manfaat lainnya. Berikut adalah rincian biaya produksi swir pepaya goreng.

- Produksi 1hari

1 hari $=10$ bungkus

1 bulan $=300$ bungkus

- Penjualan 1 bulan

1 bungkus = Rp 12.000

1 bulan $=300 \times \operatorname{Rp} 12.000=\operatorname{Rp} 3.600 .000$ 
- Profit 3 bulan

3 x Rp 3.600.000 = Rp 10.8000.000

Total profit yang diperoleh

Rp 10.800.000 - Rp 8.282.000 = Rp 2.518.000

Profit 1 bulan

Rp 2.518.000 : $3=$ Rp 840.000

\section{KESIMPULAN DAN SARAN}

\section{KESIMPULAN}

Kesimpulan yang adapat diambil dari penelitian ini adalah peneliti dapat memberikan sebuah metode baru untuk meningkatkan nilai ekonomi dari buah papaya dengan membuat olahan Suwir papaya goreng dengan rasa dan pengemasan yang berbeda sehingga mampu dapat menarik konsumen untuk membeli produk baru dengan bahan dasar buah papaya.

\section{S A R A N:}

Dari penelitian ini diharapkan peneliti dapat memberikan sebuah motivasi kepada para ibu-ibu pada sebuah kelompok disebuah desa untukmengemjbangkan usaha yang mana membuat sebuah produk olahan menjadi lebih memiliki nilai jual dan nilai ekonomi yang tinggi. Harapan dukungan dari pemerintah desa setempat untuk dapat memberikan dukungan kepada kelompok-kelompok masyarakat kecil dalam upaya peningkatan kesejahteraan perekonomian keluarga.

\section{DAFTAR PUSTAKA}

Kalie, Moehd. Baga. 1983. Bertanam Pepaya. Karya Bami. Jakarta 1996. Bertanam Pepaya. Penebar Swadaya. Jakarta

Muhidin, Dudung. 1999. Agrobisnis Papain dan Pektin. Penebar Swadaya. Jakarta

Rukmana, Rahmat. 1995. Pepaya Budidaya dan Pasca Panen. Kanisius. Yogyakarta

Steenis, Van, E.C.G.J. 1997. Flora. Pertja. Jakarta

Soedirdjoatmodjo, M.D Soetomo. 1985. Bertanam Pepaya. Karya Bani. Jakarta 